〔129〕ポリプロピレンの電気伝導性に及ぼす球晶の影響

第 1 報 球晶の数の影響

(1966 年 5 月11日受理)

井出茂*

要 旨 直径約 $20 \mu$ の球晶を含むボリブロビレンフィルムの電気伝導率を $80 \sim 40^{\circ} \mathrm{C}$ の範囲で測 定し, 球晶数と電導性との関係を検討した。伝導率は球晶数にほぼ比例して増大し, 電導の活性化 エネルギーは，見かけ上球晶数および電界強度に依存した。球晶 1 個を流れる洩れ電流は, これと 同体積で球晶を含まない部分を通過する電流の約10７0倍であった。このような球晶による伝導性 の変化は，主として球晶の内部，またはその境界に形成された微細な割れに起因するすのであると 推定される。結晶化度の差による電気伝導密,および活性化エネルギーの变化はほとんど認められ ない。

\section{1. 緒言}

重合体の電気的性質か，その化学的組成のみでなく， 物理的構造によっても変化することはよく知られてい る。とくに重合体の結晶化度や配向度が電気的性質に与 える影響については, すでに詳細な研究が行なわれてい る1,2)。一方, 結晶性重合体は結晶化の過程でしばしば球 晶を生成し, そのために物理的あるいは機械的性質が变 化することも広く知られているところである。

結晶性重合体は誘電体，あるいは電気絶縁材料として 広く使用されているが, 球晶の生成によって電気的性質 がどのように変化するかは，ほとんど知られていない。

このため本研究では, 直径約 $20 \mu$ の球晶を合むポリプ ロビレンフィルムを用いて, 球晶の数と電気伝導性との 関係を検討し，二三の考察を行なった。

\section{2. 実験方 法}

\section{1 試 料}

ポリプロピレンフィルム(厚さ $0.04 \mathrm{~mm}$ ) は三菱油化製 の市販品を用いた。このフィルムをフェロタイプ板に密 着固定し, 窒素気流中で $170^{\circ} \mathrm{C}$ に加熱して溶融後, その 一部を冷水に浸して急冷し，他の部分は放冷した。次に 再びこのフィルムを窒素気流中で $140^{\circ} \mathrm{C} て ゙ 1$ 時間熱処 理した。

球晶の数および大きさは偏光顕微鏡写真から求めた。 急冷された部分の結晶の大きさは約 $1 \mu$ であり, 徐冷さ れた部分には平均 $20 \mu$ の球晶が生成した。試料および 球晶を Fig. 1 と Fig. 2 に示した。

球晶が微細結晶中に散在する試料は, 溶融フィルムを 約 $130^{\circ} \mathrm{C}$ まで徐冷し，ついで冷水中に投入して作製し た。熱処理は前と同様である (Fig. 3)。

* 防衛庁技術研究本部第 1 研究所（東京都目黒区三 田13）

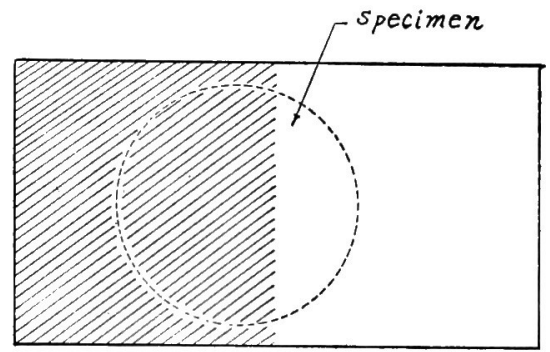

Left: annealed section, spherulite $20 \mu$ Right: quenched section, crystallite $<1 \mu$ Fig. 1. Sample.

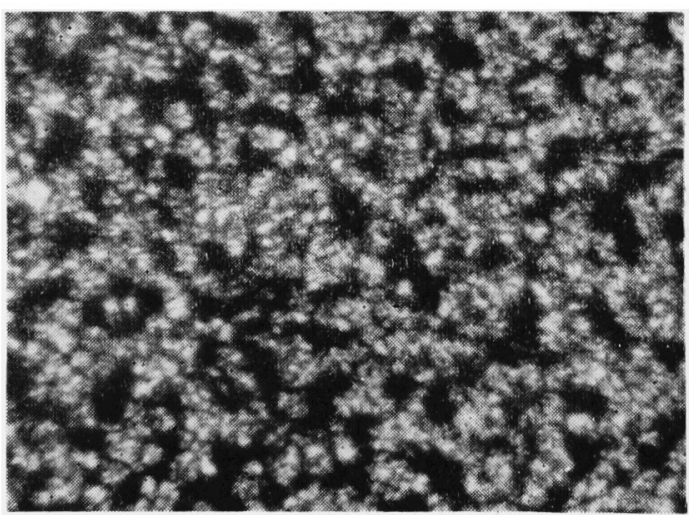

$(\times 150)$

Fig. 2. Spherulites in annealed section (sample 2 $\sim 5$ ).

低結晶化度の試料は, 溶融フィルムを直ちに冷水に投 入して作製した。

比重をエタノール-水采の浮遊法で $25^{\circ} \mathrm{C} \pm 0.1^{\circ} \mathrm{C}$ で測 定し,得られた比重から結晶化度を求めた。試料をTable 1 にまとめた。

電気伝導率測定用の試験片は, 一定量の球晶を含むよ 


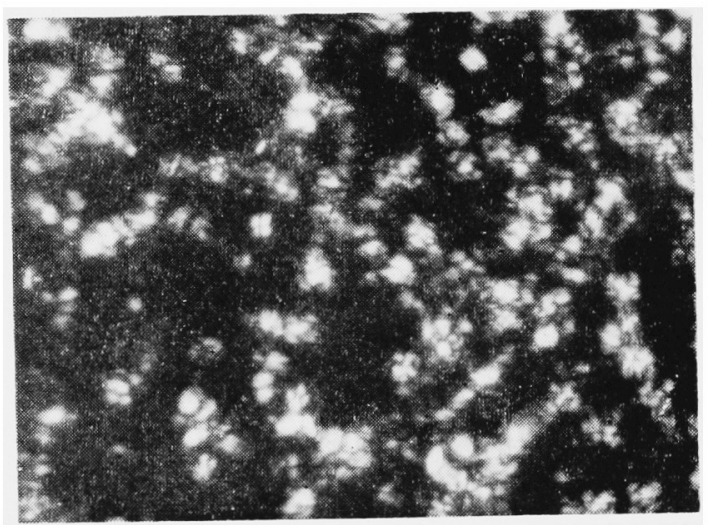

$(\times 150)$

Fig. 3. Spherulites in sample No. 6 .

Table 1. Samples.

\begin{tabular}{c|c|c|c}
\hline \hline $\begin{array}{c}\text { Sample } \\
\text { No. }\end{array}$ & $\begin{array}{c}\text { Crystal- } \\
\text { linity } \\
(\%)\end{array}$ & $\begin{array}{c}\text { Number of } \\
\text { spherulite in } \\
0.0152 \mathrm{~cm}^{3}\end{array}$ & Remarks \\
\hline 1 & 81.2 & 0 & Spherulites crowded \\
2 & 81.0 & $1.14 \times 10^{5}$ & partially " \\
3 & 81.0 & $2.28 \times 10^{5}$ & $"$ \\
4 & 80.5 & $3.42 \times 10^{5}$ & $"$ \\
5 & 80.2 & $4.56 \times 10^{5}$ & " \\
6 & 81.0 & $2.46 \times 10^{5}$ & Spherulites are \\
7 & 39.7 & 0 & scattered \\
\hline
\end{tabular}

うに試料から切り取った直径 $66 \mathrm{~mm}$ の円形フィルムに スズハク製 (厚さ $0.02 \mathrm{~mm}$ ) の電極およびガードリング を,シリコングリースで貼りつけたものである。

主電極の面積は $3.8 \mathrm{~cm}^{2}$ で, ク゚リース層の厚さは $0.4 \mu$ 以下である。グリース層の抵抗はポリプロピレンのそれ に比してきわめて小さいから無視できる。

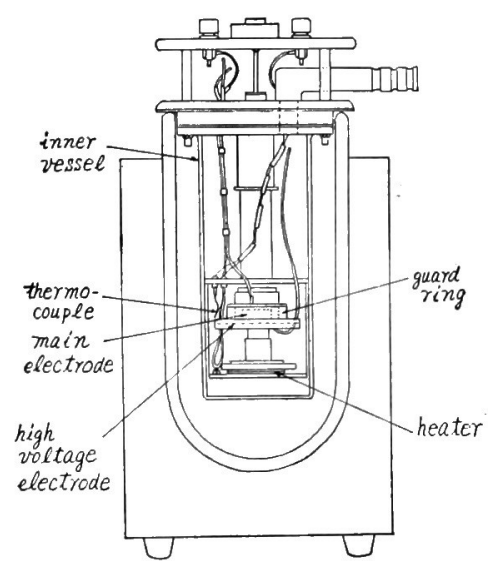

Fig. 4. Sample vessel for measuring of conductivity.

\section{2 電気伝導率の測定}

電気伝導率は洩れ電流の測定によって求めた。測定は シールドされたタケダ理研製振動容量型電位計 TR-81 を用いて行なった。

Fig. 4 に示した試料容器内のヒーターで試験片を 85 ${ }^{\circ} \mathrm{C}$ に加熱し，試料温度が一定になった後，95 V または $570 \mathrm{~V}$ の直流電圧を印加した。

吸収電流が消滅して電流がー定になってから, 徐泠し て各温度の電流值を記録した。冷却速度は $4 \sim 8 \mathrm{~min} /{ }^{\circ} \mathrm{C}$ である。

温度の測定は高圧電極にとりつけた熱電対で行ない, 熱膨張による試験片の寸法の変化は補正しなかった。

\section{3. 結 果}

\section{1 球晶を含まないものの伝導性}

試料中に球晶が含まれていないときは, 結晶化度の差 に基く電気伝導率の変化はほとんど認められない。

Fig. 5 および Fig. 6 に示したように, 結晶化度が 39.7 \%から $81.2 \%$ に增加したとき， $24 \mathrm{kV} / \mathrm{cm}$ の電界強度で は, 伝導率は約 2 倍に増加したが, $144 \mathrm{kV} / \mathrm{cm}$ では, そ れらはほぼ等しい。

電導の活性化エネルギーは, $24 \mathrm{kV} / \mathrm{cm}$ の電界では結

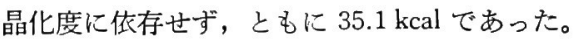

高電界のもとでは，活性化エネルギーは，ともに減少 する傾向が認められた。

\section{2 球晶による伝導性の変化}

Fig. 7 に示したように, $\log K$ はほほ球晶数に比例し

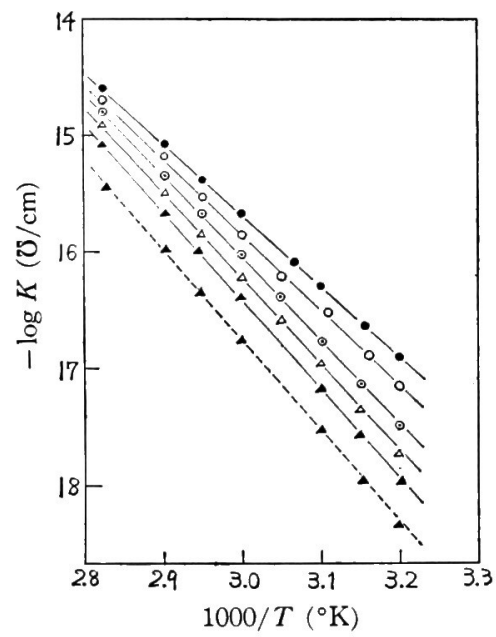

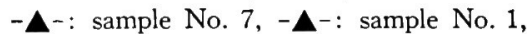
$-\triangle^{-}$: sample No. $2,-\bigcirc-$ : sample No. 3 , -O-: sample No. 4, --: sample No. 5

Fig. 5. Logarithm of specific conductance plotted against reciprocal absolute temperature at 24 $\mathrm{kV} / \mathrm{cm}$. 


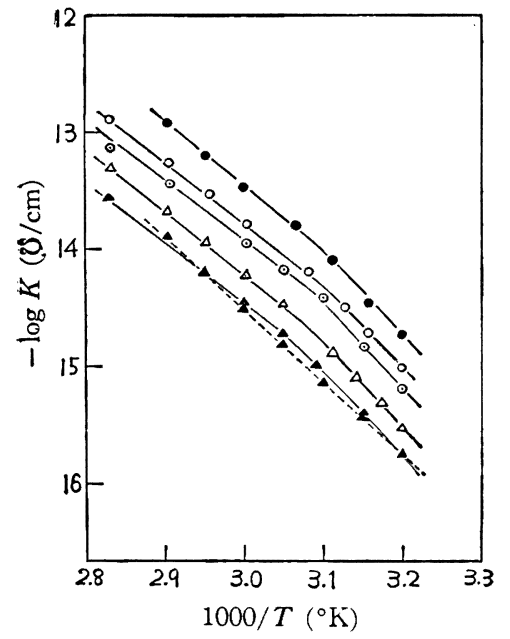

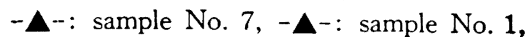
$-\triangle-$ : sample No. 2, -๑-: sample No. 3, -O-: sample No. 4, -O-: sample No. 5

Fig. 6. Logarithm of specific conductance plotted against reciprocal absolute temperature at 144 $\mathrm{kV} / \mathrm{cm}$.

て増大した。その増加率は電界強度にはほとえど依存し ない。球晶の全容積が試験片のそれの約 $13 \%$ 占めたと きの電気伝導率は, 球晶を含まないものの約10咅にも増 大した。

球晶を含むものの洩れ電流は，すべての球晶が電導に 等しく関与すると仮定すれば，（1）式で示すことができ る。

$$
I=I_{c} S_{c}+a N
$$

\section{$I: N$ 個の球晶を含む試験片の洩れ電流}

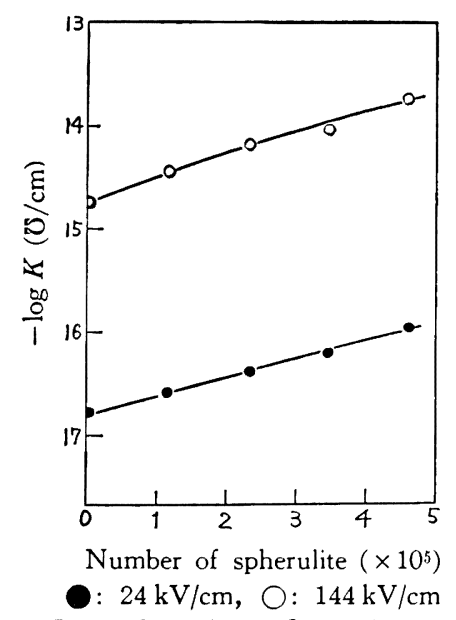

Fig. 7. Logarithm of specific conductance plotted against number of spherulite at $55^{\circ} \mathrm{C}$.

\section{$I_{c}$ ：球晶を含まないものの洩れ電流 \\ $S_{c}$ ：試験片中の球晶以外の部分の体積 \\ $a$ : 球晶 1 個の洩九電流 \\ $N$ : 試験片中の球晶数}

(1)式を用いて得られた球晶 1 個の洩れ電流は, $55^{\circ} \mathrm{C}$ で電界強度 $24 \mathrm{kV} / \mathrm{cm}$ のとき $1.8 \times 10^{-17} \mathrm{~A}, 144 \mathrm{kV} / \mathrm{cm}$

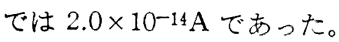

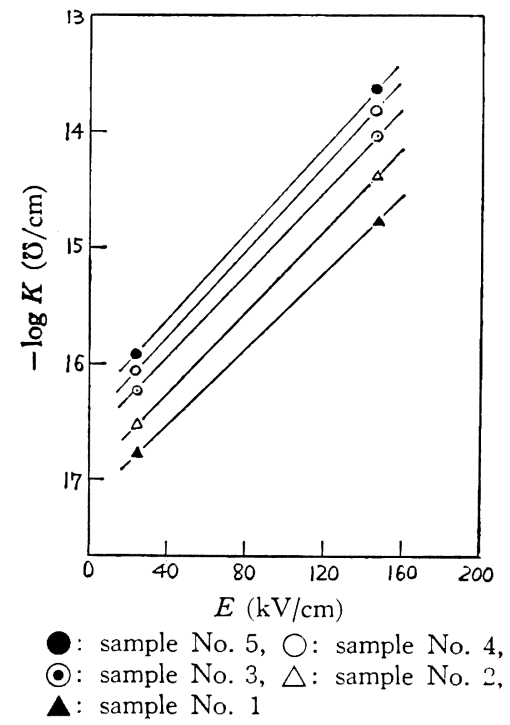

Fig. 8. Logarithm of specific conductance plotted against field strength at $55^{\circ} \mathrm{C}$.

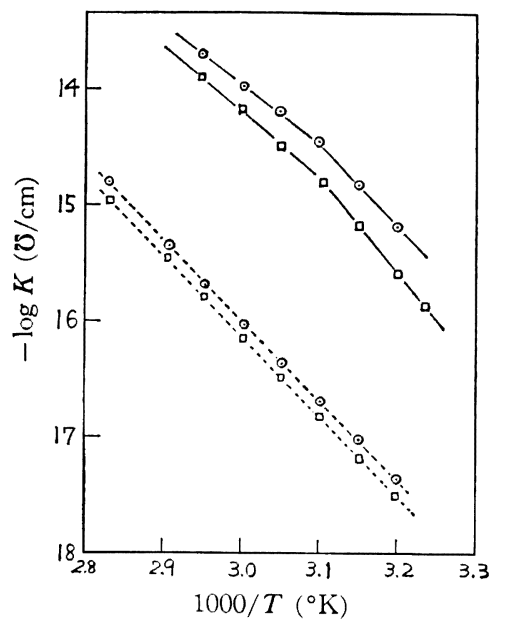

sample No. 3

$$
\begin{aligned}
& \text { - }-: 144 \mathrm{kV} / \mathrm{cm},-\bigcirc-: 24 \mathrm{kV} / \mathrm{cm} \\
& \text { sample No. } 6 \\
& -\square-: 144 \mathrm{kV} / \mathrm{cm}, \quad-\square-: 24 \mathrm{kV} / \mathrm{cm}
\end{aligned}
$$

Fig. 9. Logarithm of specific conductance plotted against reciprocal absolute temperature. 
Table 2. Specific conductance and conduction activation energy.

\begin{tabular}{|c|c|c|c|c|c|c|c|c|}
\hline \multirow{3}{*}{$\begin{array}{c}\text { Sample } \\
\text { No. }\end{array}$} & \multirow{3}{*}{$\begin{array}{l}\text { Number } \\
\text { of } \\
\text { spherulite }\end{array}$} & \multicolumn{3}{|c|}{ Field strength $24 \mathrm{kV} / \mathrm{cm}$} & \multicolumn{4}{|c|}{ Field Strength $144 \mathrm{kV} / \mathrm{cm}$} \\
\hline & & \multirow{2}{*}{$\begin{array}{c}\text { leakage } \\
\text { current } \\
\text { at } 55^{\circ} \mathrm{C} \\
(\mathrm{amp})\end{array}$} & \multirow{2}{*}{$\begin{array}{c}\text { specific } \\
\text { conductance } \\
\text { at } 55^{\circ} \mathrm{C} \\
(\mho / \mathrm{cm})\end{array}$} & \multirow{2}{*}{$\begin{array}{l}\text { activation } \\
\text { energy } \\
\text { at } 55^{\circ} \mathrm{C} \\
\text { (kcal) }\end{array}$} & \multirow{2}{*}{$\begin{array}{c}\text { leakage } \\
\text { current } \\
\text { at } 55^{\circ} \mathrm{C} \\
(\mathrm{amp})\end{array}$} & \multirow{2}{*}{$\begin{array}{c}\text { specific } \\
\text { conductance } \\
\text { at } 55^{\circ} \mathrm{C} \\
(\delta / \mathrm{cm})\end{array}$} & \multicolumn{2}{|c|}{ activation energy } \\
\hline & & & & & & & $55^{\circ} \mathrm{C}$ & $42^{\circ} \mathrm{C}$ \\
\hline 1 & 0 & $0.16 \times 10^{-11}$ & $0.18 \times 10^{-16}$ & 35.1 & $0.10 \times 10^{-8}$ & $0.19 \times 10^{-14}$ & 26.7 & 30.5 \\
\hline 2 & $1.14 \times 10^{5}$ & $0.22 \times 10^{-11}$ & $0.24 \times 10^{-16}$ & 30.0 & $0.17 \times 10^{-8}$ & $0.32 \times 10^{-14}$ & 26.7 & 30.8 \\
\hline 3 & $2.28 \times 10^{5}$ & $0.35 \times 10^{-11}$ & $0.39 \times 10^{-16}$ & 30.0 & $0.32 \times 10^{-8}$ & $0.61 \times 10^{-14}$ & 26.7 & 30.8 \\
\hline 4 & $3.42 \times 10^{5}$ & $0.62 \times 10^{-11}$ & $0.68 \times 10^{-16}$ & 29.1 & $0.45 \times 10^{-8}$ & $0.86 \times 10^{-14}$ & 26.2 & 30.3 \\
\hline 5 & $4.56 \times 10^{5}$ & $0.10 \times 10^{-10}$ & $0.11 \times 10^{-15}$ & 29.1 & $0.10 \times 10^{-7}$ & $0.19 \times 10^{-13}$ & 29.4 & 31.5 \\
\hline 6 & $2.46 \times 10^{5}$ & $0.30 \times 10^{-11}$ & $0.33 \times 10^{-16}$ & 30.0 & - & - & - & - \\
\hline 7 & 0 & $0.68 \times 10^{-12}$ & $0.74 \times 10^{-17}$ & 35.1 & $0.78 \times 10^{-9}$ & $0.15 \times 10^{-14}$ & 28.6 & 一 \\
\hline
\end{tabular}

これは球晶を含まないもの(球晶と同体積)のそれの約 30 倍および 70 倍に相当するものである。

いずれの試料も電導率はオーム則に従わないが，オー ム則からのずれは, 球晶数とともにわずかに增大する傾 向が認められた(Fig. 8)。

球晶が微細結晶中に散在して, 球晶相互の重なりが少 ないときは，たとえ球晶数が等しくても，それらが密集 しているものに比べて, 電気伝導率はやや小さい。

電導の活性化エネルギーは Table 2 に示したように, 見かけ上球晶数とともに低下する傾向がある。電界強度 が增すと, 活性化エネルギーは変化したが, 球晶数に対 する依存性は明らかでない。

\section{4. 考察}

ポリプロピレンの電気伝導性については，すでに興味 深い研究がなされている。Foss ${ }^{3)}$ らは結晶化度の異なっ た 2 種のポリプロピレンの電気伝導性を研究し, 伝導率 や電導の活性化エネルギーが結晶化度に依存しないこと を認め，このポリマーの電導の支配的因子は，担体の易 動度よりもむしろその濃度の温度依存性にあると推諭し ている。

われわれの結果も，球晶を含まないものについては Foss らの得た結晶とほぼ一致している。

しかし,ポリマー中に球晶が形成されると, 球晶の数 が增すに従って伝導率は增大し, また見かけ上, 活性化 エネルギーの球晶数および電界強度への依存性が認めら れる。

本実験の温度範囲では, 球晶 1 個の洩れ電流は，これ と同体䅪をもつ微細結晶部分のそれの 10〜70 倍にも達 し，しかもFig. 10 に見られるように，前者の温度依存 性は後者に比較してかなり小さい。

このような現象は個々の球晶に微細結晶とは違った電 临の要因があることを示すものである。

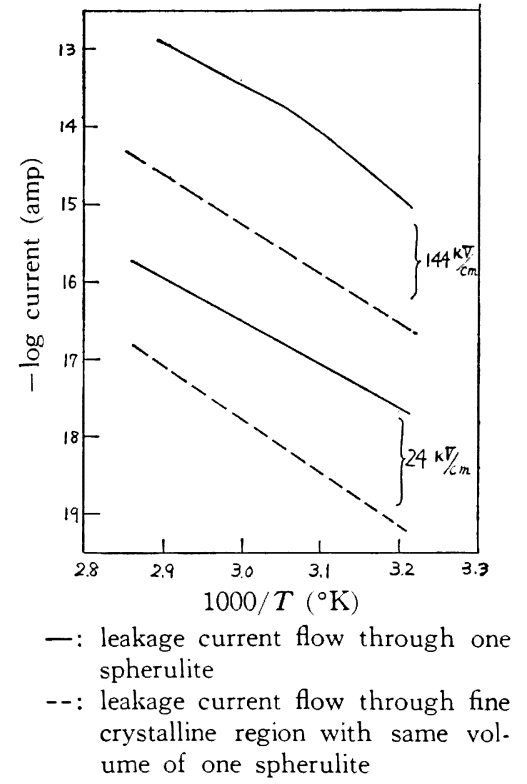

Fig. 10. Logarithm of leakage current plotted against reciprocal absolute temperature.

この要因の一つは球晶の結晶構造に起因するものであ り，他は球晶内部のなんらかの欠陥によるものであると 考えられるが，このいずれが支配的であるかは，本実験 では明らかにすることはできなかった。

しかし，Stuart4）はポリプロピレンの結晶化の際に粗 大球晶中に割れができることを拡散と浸透から推論し， また同様な割れが Inoue ${ }^{5)}$ によっても顕微鏡的に確認さ れている。

さらに Reding 6) らはフロロセンを熱処理後徐冷する か, あるいはこれを熱老化させることにより破壊電圧が 低下することを認め，これが球晶内あるいはその境㽞の 
微細な割れに起因するものであると報告している。

このような事実から，本実験で認められた球晶による 電気伝導性の変化も, 主として球晶の割れによるもので あろうと考えられる。

本実験で得られた $20 \mu$ の球晶の洩れ電流は，これと同 体積をもつ微細結晶部分のそれの 10〜70 倍であったが, この值は熱処理の条件や球晶の重なりの状態によって異 なるであろうし，また球晶がさらに大きくなれば洩れ電 流は著しく增すことが推測されるが，これらについては 次報にゆずりたい。

付記：ご指導を賜わった丸善石油化学株式会社川 畸明裕氏ならびに当研究所浦井達夫, 斎藤秀夫両氏に
感謝いたします。

$$
\text { 文献 }
$$

1) L. Amborski: J. Polymer Sci., 62, 331 (1962)

2) Сажин В. И.: Высокомол Соед., 6, 137 (1964)

3) R. A. Foss, W. Dannhauser: J. Appl. Polymer Sci., 7, 1015 (1963)

4) H. A. Stuart: Werkstoffe u. Korrosion, 13, 12 (1962)

5) M. Inoue: J. Polymer Sci., 55, 443 (1963)

6) F. P. Reding, A. Brown: Ind. \& Eng. Chem., 46, 1962 (1954)

\title{
Effect of Spherulite on Electrical Conductive Property of Polypropylene
}

\section{Effect of Number of Spherulite}

\section{By Shigeru Ide*}

\begin{abstract}
The direct current conductivity of polypropylene films with spherulite of average size of about $20 \mu$ was measured as a function of spherulite number, temperature $\left(80 \sim 40^{\circ} \mathrm{C}\right)$ and field strength (24 and $144 \mathrm{kV} / \mathrm{cm}$ ).

It was found that conductivity was increased nearly proportional to spherulite number and conduction activation energy apparently depended on spherulite number and field strength.

Leakage current flow through one spherulite increased from 10 to 70 times of that of non-spherulite region with same volume to one spherulite.

It is presumed that these change of conductive property due to existence of fine crackings in or boundaries of spherulites.

The conductivity and conduction activation energy appear to be relative insensitive to polymer crystallinity.
\end{abstract}

